УДК 15(091)

ПАМЯТИ ПРОФЕССОРА В.Г. БЕЛИКОВА.

(О)2013 Боровский Б.В., Ларский М.В., Фролова О.О.

Пятигорский медико-фармацевтический институт - филиал ГБОУ ВПО ВолгГМУ Минздрава России, г. Пятигорск

\title{
Резюме
}

Статья посвящена основным жизненным вехам профессора, доктора фармацевтических наук, заслуженного деятеля науки РФ Беликова В.Г., внесшего большой вклад в развитие отечественного фармацевтического образования и науки, более 30 лет возглавлявшего ведущий фармацевтический вуз страны.

Ключевые слова: В.Г. Беликов, фармацевтическая химия, фармацевтическое образование и наука, Пятигорский фармацевтический институт.

\section{IN MEMORY OF PROFESSOR V.G. BELIKOV}

\author{
B.V. Borovsky, M.V. Larsky, O.O. Frolova
}

\section{Pyatigorsk Medical and Pharmaceutical Institute-a branch of Volgograd State Medical University, Pyatigorsk}

Article is devoted to basic life milestones of Professor, Doctor of Pharmacy, Honored Scientist of Russia V. G. Belikov, who made a great contribution to the development of domestic pharmaceutical education and science, more than 30 years headed the leading pharmaceutical institution of the country.

Key words: VG Belikov, pharmaceutical chemistry, pharmaceutical science and education, Pyatigorsk Pharmaceutical Institute.

3 сентября 2013 г. исполнился год с момента ухода из жизни выдающегося ученого отечественной фармации, заслуженного деятеля науки РСФСР, профессора, доктора фармацевтических наук Владимира Георгиевича Беликова.

В.Г. Беликов родился в селе Степном Ставропольского края. По окончании школы был призван в ряды Советской Армии. С февраля 1943 г. В.Г. Беликов принимал участие в боях на Северо-Кавказском фронте. Осенью 1943 г. был направлен в Краснознаменную Каспийскую военную флотилию и прослужил в Военно-Морском флоте еще 7 лет (рис. 1).

В 1950 г. В.Г. Беликов поступил в Пятигорский фармацевтический институт. В 1954 году за отличные успехи в учебе Министерство Образования присудило ему стипендию им. И.В. Сталина. Сразу же по окончании института в 1955 г. был зачислен в аспирантуру на кафедру фармацевтической химии (рис. 2).

Одновременно с учебой в аспирантуре Владимир Георгиевич работал в родном институте - лаборантом, старшим лаборантом на различных кафедрах. В 1960 г. в стенах ВНИХФИ защитил кандидатскую диссертацию, а потом стал ассистентом, доцентом, а в 1972 году - профессором на кафедре фармацевтической химии.

В 1961 г. В.Г. Беликова назначили на должность проректора по учебной и научной работе института. А в 1964 году он возглавил Пятигорский фармацевтический институт сначала как исполняющий обязанности ректора и через год - как полноправный ректор. На этом посту он проработал 31 год. 


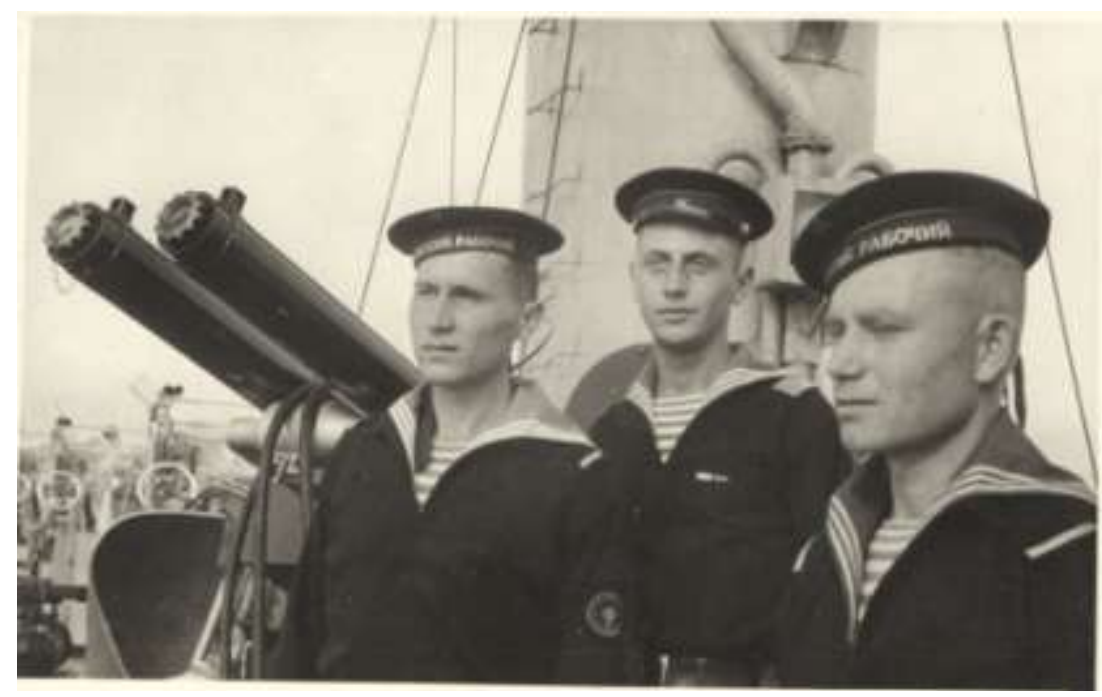

Рисунок 1 - Служба в Советской армии и Военно-Морском Флоте

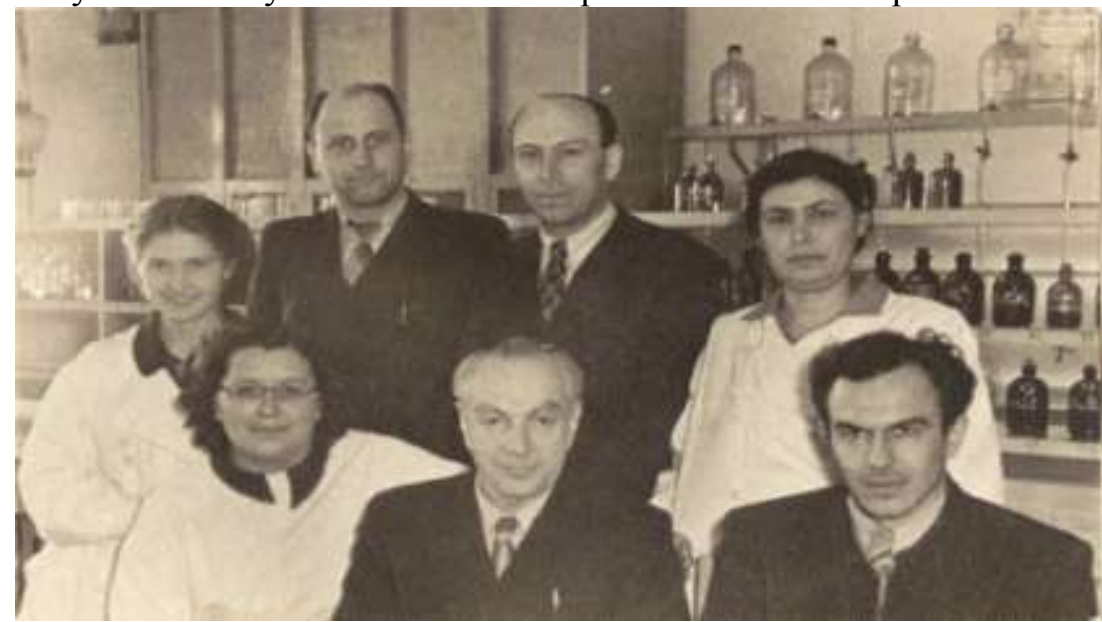

Рисунок 2 - В аспирантуре 1955 г.

Под его руководством Пятигорский фармацевтический институт стал одним из крупных фармацевтических ВУЗов страны, была существенно расширена материальная база института: построен новый административно-учебный корпус (рис. 3), три общежития, спортивнооздоровительный лагерь, создан санаторий-профилакторий, студенческая поликлиника и первая в СССР учебно-производственная аптека.

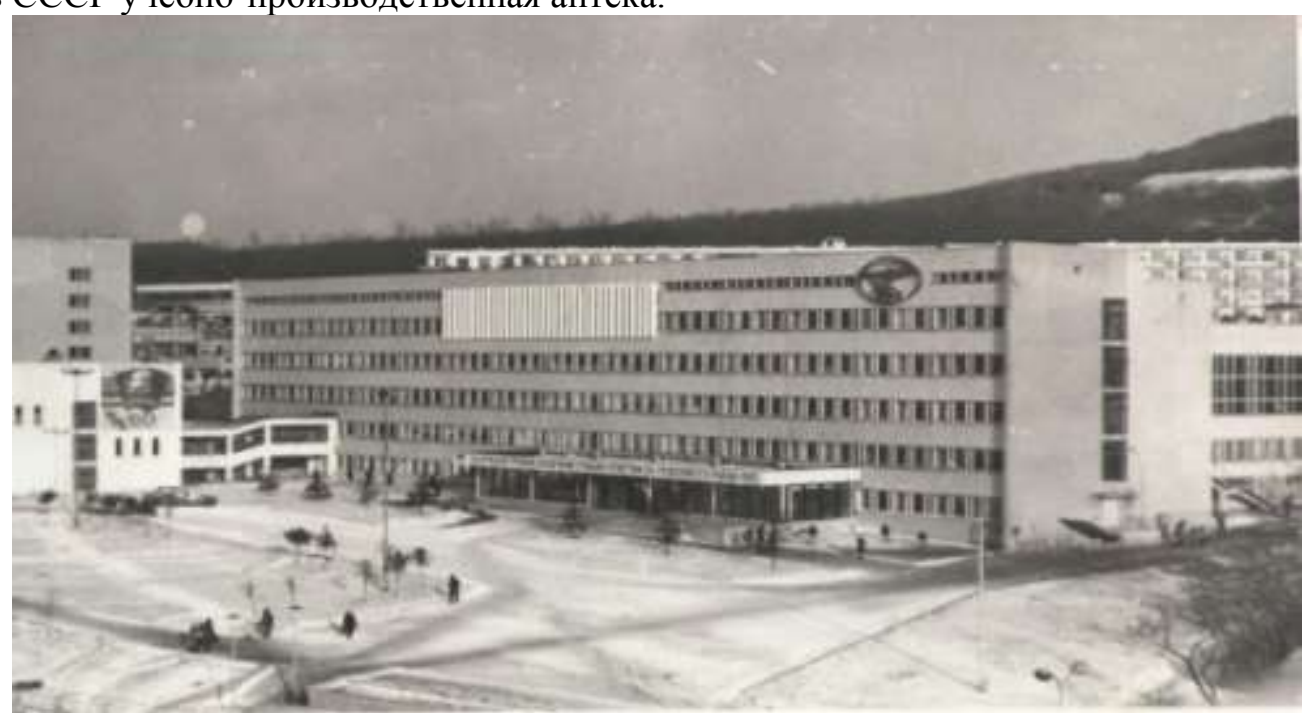

Рисунок 3 - Новый административно-учебный корпус Пятигорского фармацевтического института (1978 г.). 
Большое внимание В.Г. Беликов уделял развитию фармацевтического образования. Под его руководством и при его непосредственном участии разработана концепция высшего фармацевтического образования.

Профессор В.Г. Беликов подготовил и издал 5 изданий учебника «Фармацевтическая химия», 2 издания справочника «Синтетические и природные лекарственные средства» и ряд учебных пособий по данному предмету. Кроме того, в авторском коллективе он принимал участие в издании практикумов по фармацевтической химии. Эти книги были изданы большими тиражами и рекомендованы для обучения студентов фармацевтических вузов и фармацевтических факультетов медицинских ВУЗов России и многих стран СНГ. Кроме того, в списке опубликованных работ более 450 научных статей, 4 монографии, 15 авторских свидетельств и патентов, в том числе 3 зарубежных (США, ФРГ, Франция).

В 1970 г. В.Г. Беликов защитил диссертацию на соискание ученой степени доктора фармацевтических наук. Защита проходила в 1-м Московском медицинском институте им. И.М. Сеченова. Одновременно с работой над докторской диссертацией Владимир Георгиевич начал готовить аспирантов. В результате за прошедшие годы его учениками были выполнены 63 диссертации (4 докторские и 59 кандидатских), в том числе аспирантами из Вьетнама, Эфиопии, Йемена и Перу.

В течение 6 лет В.Г. Беликов работал экспертом Высшей аттестационной комиссии по специальности фармацевтическая химия и фармакогнозия. Был вице-президентом Ассоциации медицинских и фармацевтических ВУЗов России; действующий член совета Российского общества фармацевтов, член редакционных советов ведущих научных изданий, в том числе «Фармации» и «Химико-фармацевтического журнала»; входил в состав проблемных и методических комиссий при Министерстве здравоохранения РФ. Был членом совета ректоров края и Северо-Кавказского научного центра высшей школы, избран действительным членом Российской экологической академии и международной академии информатизации.

В.Г. Беликов принимал активное участие в подготовке и проведении Всесоюзных, Республиканских, зарубежных съездов, в том числе во Всемирном фармацевтическом конгрессе (г. Вашингтоне, США) и многих международных совещаниях по фармацевтическому образованию.

По его инициативе, в Пятигорском фармацевтическом институте в 1985 г. был создан диссертационный совет, председателем которого он являлся по 2010 г. За это время в стенах вуза было успешно защищено 36 докторских и более 400 кандидатских диссертаций по фармацевтическим наукам. Наличие диссертационного совета способствовало подготовке научных и педагогических кадров фармацевтических и медицинских вузов страны.

Несмотря на занятость, Владимир Георгиевич остаевался преподавателем высшего учебного заведения, сочетал в себе педагога и исследователя. За годы его руководства ВУЗ подготовил более 18000 провизоров и 1000 магистров фармации для 52 зарубежных стран. В 1994 г., в окончании руководства В.Г. Беликова, Пятигорский фармацевтический институт стал академией, что явилось признанием заслуг коллектива в области высшего фармацевтического образования.

С 1995 г. по 2012 г. В.Г. Беликов работал советником ректората. Кроме того с 1972 по 2006 год он был заведующим кафедрой фармацевтической химии, а затем - вплоть до последних дней - профессором этой же кафедры.

Так и работал всю жизнь с одной записью в трудовой книжке, от 1 сентября 1950 года, менялись лишь должности... Как говорил сам профессор В.Г. Беликов: «Пока я работаю, я живу...».

Правительство высоко оценило боевую, трудовую, научную и общественную деятельность. В.Г. Беликов был награжден орденами - Отечественной войны II степени, Трудового Красного Знамени и «Знак Почета», 30 медалями и двумя почетными званиями: «Заслуженный деятель науки РСФСР» и «Лауреат премии Правительства РФ в области образования» (рис. 4). Именно вручение премии стало для Владимира Георгиевича самым ярким воспоминанием, всей жизни и профессиональной деятельности. Это была заслуженно высокая оценка проделанной им научной и учебно-методической работы. 


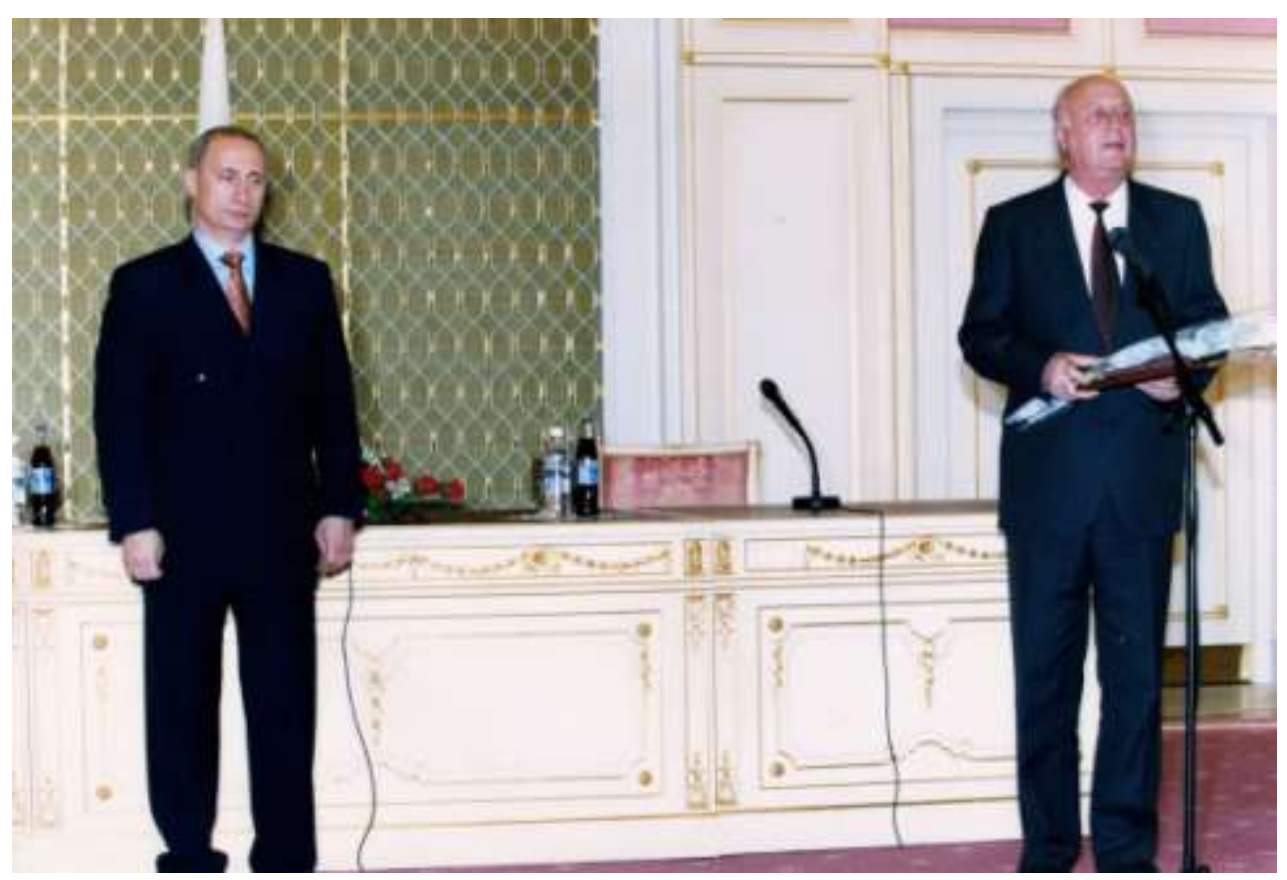

Рисунок 4 - Вручение премии Правительства РФ

Вся жизнь Владимира Георгиевича Беликова - «это скромное мужество русского интеллигента», как отметил В.В. Путин, вручая ему премию Правительства РФ в области образования в 1999 году [1].

\section{Литература}

1. Беликов В.Г. Судьбы моей нелегкие ступени: монография.- Пятигорск, 2010.- 90 с.

$* * *$

Боровский Борис Владимирович - кандидат фармацевтических наук, преподаватель кафедрь физической и коллоидной химии Пятигорского медико-фармацевтического института - филиала ВолгГМУ. E-mail: boryusikxxl@rambler.ru.

Ларский Михаил Владимирович - кандидат фармачевтических наук, преподаватель кафедры ФТВ, гигиены и экологии Пятигорского медико-фармацевтического института - филиала ВолгГМУ.

Фролова Ольга Олеговна, преподаватель кафедры фармаџевтической химии Пятигорского медико-фармацевтического института - филиала ГБОУ ВПО ВолгГМУ Минздава России. E-таіl: oxifarm@mail.ru 